\title{
Single-Item Self-Esteem Scale: Brazilian Adaptation and Relationship with Personality and Prosocial Behavior
}

\author{
Carlos Eduardo Pimentel - Universidade Federal da Paraíba, João Pessoa, Brasil \\ Flávia Marcelly de Sousa Mendes da Silva - Universidade Federal da Paraíba, João Pessoa, Brasil \\ Jérssia Laís Fonseca dos Santos - Universidade Federal da Paraíba, João Pessoa, Brasil \\ Karen Guedes Oliveira - UNINASS AU, João Pessoa, Brasil \\ Nájila Bianca Campos Freitas - Universidade Federal da Paraíba, João Pessoa, Brasil \\ Ricardo Neves Couto - Universidade Federal da Paraíba, João Pessoa, Brasil \\ Tátila Rayane de Sampaio Brito - Universidade Federal da Paraíba, João Pessoa, Brasil
}

\begin{abstract}
The objective of this correlational study was to test the psychometric properties of convergent validity of the Single-Item SelfEsteem Scale (SISES). The correlation between the SISES and the Rosenberg Self-Esteem Scale (RSE), which also measures self-esteem, and with scales that measure other variables (personality and prosocial behaviors) was also tested. A total of 203 students, aged 18 to 58 years $(M=23.49, \mathrm{SD}=5.84)$, from public and private universities in the city of João Pessoa, participated in the study. The Pro-Socialness Scale (PSS), the Ten-Item Personality Inventory (TIPI), the SISES, the RSE, and a demographic questionnaire were used. The results showed that the Portuguese version of the SISES presents satisfactory validity. Therefore, as this study shows a correlation between self-esteem and personality traits and socio-demographic variables, it contributes to the scientific literature in this field and provides an alternative for measuring self-esteem.
\end{abstract}

Keywords: self-esteem; convergent validity; personality; prosocial behaviors.

\section{Single-Item Self-Esteem Scale: Adaptação Brasileira, Relações com Personalidade e Comportamentos Pró-Sociais}

\section{Resumo}

O presente estudo correlacional tem por objetivo verificar parâmetros psicométricos de validade convergente da Single-Item Self-Esteem Scale - SISES. Para tanto, buscou a relação com a Escala de Autoestima de Rosenberg, que mede esse mesmo construto, e com escalas que mensuram outras variáveis: personalidade e comportamentos pró-sociais. Participaram da pesquisa 203 universitários de instituições públicas e privadas da cidade de João Pessoa, com idade entre 18 e 58 anos $(M=23,49, D P=$ 5,84). Foram utilizados a Escala de Pró-sociabilidade, o Ten-Item Personality Inventory (TIPI), a Single-Item Self-Esteem Scale (SISES), a Escala de Autoestima de Rosenberg e um questionário demográfico. O resultado desse estudo constatou que a versão em português da SISES apresenta evidências de validade satisfatórias. Considera-se que esse estudo, apresentando seus correlatos com os traços de personalidade e variáveis sociodemográficas, contribui para ampliar a produção científica da temática e disponibiliza uma alternativa para a tarefa de mensuração da autoestima.

Palavras-chave: autoestima, validade convergente, personalidade, comportamentos pró-sociais

\section{Single-Item Self-Esteem Scale: Adaptación Brasileña, Relaciones con la Personalidade y Conducta Prosocial}

\section{Resumen}

Este estudio correlacional tiene como objetivo verificar los parámetros psicométricos de validez convergente de la Single-Item Self-Esteem Scale - SISES. Con este fin, se buscó la relación con la escala de autoestima de Rosenberg, que mide el mismo constructo y escalas que miden otras variables: la personalidad y los comportamientos prosociales. Los participantes fueron 203 estudiantes de instituciones públicas y privadas de la ciudad de João Pessoa, con edades comprendidas entre 18 y 58 años $(M=$ 23.49, DE = 5.84). Se utilizaron la Escala Prosociabilidad, el Ten-Item Personality Inventory (TIPI), el Single-Item Self-Esteem Scale (SISES), la Escala de Autoestima de Rosenberg y un cuestionario demográfico. El resultado de este estudio encontró que la versión en portugués de la SISES presenta pruebas satisfactorias de validez. Se considera que este estudio, con sus correlacionados con los rasgos de personalidad y las variables sociodemográficas, contribuye para aumentar la producción científica de la temática y ofrece una alternativa a la tarea de medición de la autoestima

Palabras clave: autoestima, validez convergente, personalidade, conducta pro-social

\section{Introduction}

Studies on self-esteem have been garnering attention in the last several years, as can be observed by typing the keyword "self-esteem" in the Google Scholar search tool, which produces 220,000 results when including results in Portuguese and Spanish. Self-esteem is defined as a self-evaluative process that an individual 
performs and maintains. This evaluation expresses a set of feelings and thoughts regarding an individual's selfworth, resulting in an attitude of approval or rejection of oneself (Rosenberg, 1989). The definition of selfesteem is very complex, as it encompasses perceptions, appraisal of beliefs, and affectivity. Thus, the construct of self-esteem is personal and is strongly influenced by the social and cultural setting to which the individual belongs (Schultheisz \& Aprile, 2013).

The literature shows that to understand/study selfesteem, other variables, such as personality (Bagozzi \& Heatherton, 1994; Daly \& Wilson, 1983) and prosocial behaviors (Brown \& Smart, 1991; Laible, Carlo, \& Roesch, 2004), must be considered and the relationship between them tested.

\section{Self-esteem: concept and preliminary considerations}

Self-esteem refers to a set of personal values that is expressed through attitudes an individual harbors toward him/herself and represented by the extremes of self-acceptance or self-rejection, recognition of skills or inabilities, success or failure. Therefore, its evaluative aspect is essential (Coopersmith, 1989). In addition, self-esteem is understood as an individual's sense of self-worth and the evaluation he/she makes of him/herself in terms of his/her competence (Assis \& Avanci, 2004). Self-esteem can be summarized into two main dimensions: the sense of being loved and the sense of being capable (Humphreys, 2001).

Self-esteem is developed through social interaction, which begins in the first years of life from information the child receives, in particular from the most important, present, and significant individuals in the initial stage of his/her life (Assis \& Avanci, 2004). However, while the development of self-esteem occurs in childhood, it tends to remain stable over time and in different contexts in adulthood (Hutz \& Zanon, 2011).

Variations related to gender have been examined in a number of studies on self-esteem (Bandeira \& Hutz, 2010). In women, self-esteem is related to success in interpersonal relationships; in men, self-esteem is gained from success in achieving proposed goals (Heatherton \& Wyland, 2003). This construct requires further investigation, and measures used to perform this task are discussed next.

\section{Self-esteem scales and the Single-Item Self-Esteem Scale (SISES)}

Self-esteem is a concept studied worldwide. Therefore, the use of scales to measure it is a common practice among researchers. James Battle, based on his self-esteem theory, has developed three versions of the Culture-Free Self-Esteem Inventory (CFSEI) since the early 1990s, varying them according to the target group, with versions for children, adolescents, and adults. This instrument is composed of 40 items and contains three scales that measure general, social, and personal self-esteem (Battle, 1992). Another scale found in the literature is the State Self-Esteem Scale (SSES), which is composed of 20 items and evaluates manipulations that affect and temporarily alter self-esteem (Heatherton \& Polivy, 1991).

Regarding the practice of evaluating, the Rosenberg Self-Esteem Scale (RSE) (Rosenberg, 1989) is one of the most frequently used instruments in research worldwide (Blascovitich \& Tomaka, 1991; Heatherton \& Wyland, 2003; Weisskirch, 2016). In Brazil, several researchers have used a version of the RSE called the Escala de Autoestima de Rosenberg that was adapted and validated by Hutz (2000) and Hutz and Zanon (2011), in which the 10 items that constitute the scale represent a unifactorial structure related to a set of feelings of self-esteem and self-acceptance that evaluates overall self-esteem. Thus, this most recent version is used in the present study to investigate correlations with the SISES.

The SISES, created and validated by Robins, Hendin, and Trzeniewski (2001), contains only one item - "I have high self-esteem" - and has convergent validity with the RSE for men, women, and different age groups, in addition to near-identical correlates with several criterion measures (e.g., mental and physical health, peer ratings of group behavior, academic outcomes, and self-evaluative biases). Therefore, the SISES is recognized and suggested as an alternative measure for adults for the measurement of general self-esteem. Because the objective of this study is to test the psychometric properties of validity and reliability of the SISES, this measure will be used to achieve convergent validity with the RSE as well as with other psychological variables, such as prosocial behaviors and personality.

\section{Correlates between self-esteem and prosocial behaviors}

The prosocial behaviors addressed by positive psychology are a well-studied construct and relate to distinct variables (e.g., educational practices, selfmonitoring, postpartum depression, social context) (Barreiros, 2012; Koller, 1997; Stobaus, 2013). These behaviors are understood as actions for the benefit of others and are defined as behaviors of helping, 
comforting, sharing, and cooperating (Penner, Dovidio, Piliavin, \& Schroeder, 2005) and as actions not aimed at external reward (Eisenberg \& Mussen, 1989). Based on this, Roche (2010) groups prosocial behaviors into ten distinct classes: physical assistance; physical service; giving and sharing; verbal assistance; verbal comfort; validation and positive assessment of others; attentive listening; empathy; solidarity; positive presence; and unity.

Empirical studies (Gebauer, Riketta, Broemer, \& Maio, 2008; Isen \& Levin, 1972) show correlations between prosocial behaviors, self-esteem, and motivations, in which two fundamentally different reasons for helping are proposed: to feel pleasure and because it is one's responsibility (pressure). A noteworthy finding is that pleasure, when grounded in the prosocial motivation of helping, correlates with self-fulfillment, self-esteem, life satisfaction, and positive affect and is negatively associated with negative affect. According to Gebauer et al. (2008), prosocial life objectives, in general, increase subjective wellbeing. Self-esteem can modulate affective responses associated with prosocial behaviors (Forgas, 2002).

\section{Correlates between self-esteem and personality}

In addition to prosocial behaviors, studies have sought to correlate self-esteem and other variables, such as female vanity (Avelar \& Veiga, 2013), eating disorders, and suicidal ideation (Orth, Robins, \& Roberts, 2008). Therefore, another variable commonly used in research is personality (Hutz, et al., 2014; Nunes, Hutz, \& Nunes, 2008; Pimentel, 2012; Robins et al., 2001), which may correlate with self-esteem.

Personality is considered an association of different systems that are related to psychological attributes, that is, the pattern of functioning of each individual (Hall, Lindzey, \& Campbell, 2000). According to Allport (1973), personality is measured through its traits. Thus, it constitutes a permanent way to react to the social environment.

Studies that address the structure of personality traits suggest that they may be grouped into five aspects, creating the Big Five dimensions of personality model: (1) conscientiousness, which corresponds to motivational stability; (2) emotional stability (or its opposite pole, neuroticism), which refers to emotional adjustment; (3) agreeableness, which refers to quality of interpersonal relationships; (4) openness to experience, which corresponds to self-perception of abilities; and (5) extraversion, which refers to positive emotions
(Costa \& McCrae, 1992; Filho, Machado, Teixeira, \& Bandeira, 2012; Gosling et al., 2003; Schmitt et al., 2007; Thompson, 2008).

Based on this model, Simkin and Azzollini (2015) conducted a study discussing previous research reporting a correlation between variables such as self-esteem, religiosity, spirituality, and personality, the last based on the Five-Factor Model (FFM) of personality. In another study, Avelar and Veiga (2013) analyzed the correlation between self-esteem and personality traits with regard to female vanity and how these associations may influence the propensity to undergo cosmetic plastic surgery. The results suggest that the higher the creativity, extraversion, kindness, and need to maintain and emphasize body shape, the greater the self-esteem and, consequently, the less excessive the concern with physical appearance and the greater the positive selfevaluation of women.

Bastianello, Pacico, and Hutz (2014) studied the relationship between optimism, self-esteem, and personality using the RSE and the Big Five model. The results show that neuroticism is a negative predictor of self-esteem and optimism, namely, the higher the individual's level of emotional stability, the more positive the expectations regarding future events (optimism) and the higher the self-esteem. Similarly, in a crosscultural study, Hutz, Midgett, Pacico, Bastianello, and Zanon (2014) evaluated the relationship between hope, optimism, life satisfaction, self-esteem, and personality in Brazilian and American students. Regarding the correlation between self-esteem and personality in the Brazilian sample, a correlation between all personality factors and self-esteem was found; in particular, selfesteem was negatively associated with neuroticism and positively associated with extraversion and agreeableness. These results were replicated in the American sample, with the exception of the correlation between self-esteem and conscientiousness, which was stronger than with agreeableness.

While various studies have adopted the FFM, also called the Big Five model, or other instruments to study personality traits, these measures are composed of different numbers of items, yet they do not have abbreviated versions. Despite the effectiveness of these measures, they present several issues, for instance, participants may experience fatigue with regard to answering the questions, and the number of items may cause the instrument to become redundant (Gosling et al., 2003; Robins, Tracy, Trzesniewski, Potter, \& Gosling, 2001). 
As a result, shorter instruments are found in the literature, which measure several constructs, such as self-esteem and personality (Gosling et al., 2003; Robins et al., 2001). Regarding the evaluation of personality traits, there is a brief and frequently cited instrument in the literature called the Ten-Item Personality Inventory (TIPI), developed by Gosling et al. (2003).

The TIPI is an instrument based on the Big Five model that measures personality via 10 items corresponding to the factors extraversion, agreeableness, emotional stability, conscientiousness, and openness to experience. Each item is composed of two adjectives (with similar content) and answered on a seven-point Likert-type scale ranging from "Strongly disagree" to "Strongly agree."

Gosling et al. (2003) study showed significant correlations between the TIPI and the Big Five Inventory for all five factors: extraversion $(r=0.87)$, agreeableness $(r$ $=0.70)$, conscientiousness $(r=0.75)$, emotional stability ( $r$ $=0.81)$, and openness to experience $(r=0.65)$. In another study, using the TIPI, the researchers evaluated personality traits through social media, such as Facebook, and found significant correlations between number of friends and extraversion; in addition, openness to experience was associated with number of friends and connection with the network (Gosling, Augustine, Vazire, Holtzman, \& Gaddis, 2011).

Pimentel (2012), also using the TIPI, tested the relationship between self-esteem and personality and found a significant correlation $(r=0.40)$ between self-esteem and agreeableness, which corroborates the results of previous studies, such as Robins et al. (2001). Therefore, self-esteem and personality are expected to present strong correlations, and these variables, which have been extensively investigated by researchers, are also explored in the present study. Additionally, the influence of socio-demographic variables (e.g., gender, type of educational institution, income) on the variations in self-esteem levels are evaluated through $t$ tests and analyses of variance (ANOVAs), as these analyses are key tools in the scientific studies that address these topics (Bandeira \& Hutz, 2010).

Thus, the objective of the present study is to adapt and gather evidence of validity of the SISES, seeking a correlation with the RSE, as both scales measure the same construct. In addition, the relationship between self-esteem and other variables that, in theory, should be correlated (e.g., personality and prosocial behaviors) is tested, and the influence of socio-demographic variables is identified.

\section{Method}

\section{Study design}

This is a correlational study of ex post facto nature, with a psychometric emphasis.

\section{Participants}

A total of 203 students from public (57.6\%) and private $(42.4 \%)$ higher education institutions in the city of João Pessoa, with ages ranging from 18 to 58 years (mean $[\mathrm{M}]=23.49$, standard deviation $[\mathrm{SD}]=5.84$ ), the majority of which were female (63.1\%), single (84.7\%), and heterosexual $(87.2 \%)$, took part in the study. The majority was Catholic (43.3\%), and $79.8 \%$ reported belonging to the middle class.

\section{Instruments}

Participants answered a number of pencil-andpaper type self-administered questionnaires, which are described below:

Single-Item Self-Esteem Scale (SISES): Created and validated by Robins et al. (2001) and containing only one item - "I have high self-esteem" - that is answered on a 7-point Likert-type scale ranging from $1=$ "Not very common for me" to 7 = "Very common for me."

Prosocialness Scale (PSS) (Caprara, Steca, Zelli, \& Capanna, 2005): Composed of 16 items to assess prosocialness (e.g., "I am pleased to help my friends/ colleagues in their activities;" "I am empathic with those who are in need"), which includes not only behaviors but also prosocial feelings that are measured on a five-point scale, varying from $1=$ "Never/almost never true" to $5=$ "Almost always/always true." The validated version of this scale, presented by Pimentel (2012), was used, which in the present study showed the following reliability levels: $\alpha=0.90, r_{\mathrm{i}, \mathrm{i}}=0.37$.

Ten-Item Personality Inventory (TIPI): Composed of 10 items representing pairs of adjectives, each measuring the same pole of one of the dimensions of the FFM. Half of the items represent low score levels in the construct, namely, one pole of the dimensions of the five factors, and the other half represents high levels (the other pole), for example: "extraverted, enthusiastic"; "conventional, uncreative." The factors of this scale presented test-retest reliability varying between 0.62 and 0.77 (Gosling et al., 2003). The version translated and adapted for the Brazilian context was used (Pimentel, 2012; Pimentel, Ferreira, Vargas, Maynart, \& Cardozo, 2014).

Psico-USF, Bragança Paulista, v. 23, n. 1, p. 1-11, jan./mar. 2018 
Rosenberg Self-Esteem Scale (RSE): Composed of 10 items with a unifactorial structure associated with a set of feelings of self-esteem and self-acceptance that evaluates overall self-esteem. The items, for example, "I feel that I am a person of worth, at least on an equal plane with others" and "On the whole, I am satisfied with myself," are answered on a four-point Likert-type scale ranging from "Strongly agree" to "Strongly disagree." This scale presented the following reliability levels in the present study: $\alpha=0.81, r_{\mathrm{i} . \mathrm{i}}=0.30$. The version adapted and validated by Hutz (2000) and Hutz and Zanon (2011) was used.

Demographic data: The objective was to gather the socio-demographic characteristics of the participants to describe the sample. The following variables were included: age, sex, gender, marital status, religion, and family income, among others.

\section{Procedure}

First, the SISES was translated into Brazilian Portuguese using the Back Translation method (Sousa \& Rojjanasrirat, 2010), Thus, the instrument was translated by two bilingual psychologists and subsequently backtranslated into English with the collaboration of two bilingual professors of English who were not familiar with the instrument (blind translation). After verifying the correspondence of the translations, the version was submitted to the next stage of semantic validation, following the procedures established by Pasquali (2010). Ten participants from the target population participated in this stage ( 5 men and 5 women), reviewing the instrument for possible reading and interpretation difficulties in the items. No problems regarding comprehension of the items and of instructions on how to answer them were reported.

The questionnaires were administered in a classroom, although they were answered individually. On average, the subjects took 15 minutes to conclude their participation in the study. It is important to note that this study followed the ethical recommendations for research with humans as stated in Resolution 466/2012. Participants signed a free and informed consent form agreeing to participate in the study. In addition, participants were informed that their participation in the study was voluntary and if they decided at any moment to quit they would not be punished.

\section{Data analysis}

Data were collected and then tabulated in SPSS version 21. Descriptive analyses were conducted to characterize the sample and correlations, with the objective of testing the psychometric parameters of convergent validity of the SISES. To determine the sources of variation in self-esteem levels, an analysis of variance (ANOVA) was conducted with only one dependent variable (SISES score), and several of the sample's socio-demographic characteristics were used as independent variables. In addition, to compare two conditions regarding the sources of variations in selfesteem levels, Student's $t$ test for independent samples was applied using other socio-demographic variables of the participants.

\section{Results}

The results are presented in the following order: first, the descriptive statistics of the instruments used and the results of the convergent validity of the SISES; and second, the results of the comparison analysis between the conditions regarding the variation of self-esteem levels. Subsequently, evidence regarding the validity of the SISES construct was gathered by testing the instrument's convergent validity. An instrument presents convergent validity when it correlates with another theoretically correlated instrument (Pasquali, 2010).

The results presented in Table 1 show that the general factor of the RSE $(r=0.55, p<0.001)$ presented convergent validity. Four personality factors measured by the TIPI, extraversion $(r=0.31, p<0.001)$, openness to experiences ( $r=0.24, p<0.001)$, conscientiousness $(r=0.28, p<0.001)$, and emotional stability $(r=0.30, p$ $<0.001)$ presented convergent validity varying between satisfactory and moderate, given that, as Urbina (2007) states, even consistently low correlations may indicate convergent validity. The general factor of the PSS $(r=$ $0.04, p=0.48)$ and the agreeableness factor $(r=0.03$, $p=0.59)$ presented non-significant statistical correlations. In summary, these results are, in general, similar when compared with the correlations of the SISES and the RSE and suggest evidence for convergent validity of the SISES.

Subsequently, to assess the sources of variations in self-esteem levels, an ANOVA was conducted using as dependent variables the SISES and RSE scores and as independent variables several socioeconomic characteristic of the sample, including religion, sexual orientation, and family income. The results indicate that there were no significant differences in the measurement of self-esteem levels as 
Table 1.

Descriptive statistics and correlations between the scales of this study

\begin{tabular}{llllllllll}
\hline Dimensions & Mean (SD) & 1 & 2 & 3 & 4 & 5 & 6 & 7 & 8 \\
\hline 1. SISES & $4.36(1.45)$ & 1 & $0.57^{* *}$ & 0.51 & 0.04 & $0.32^{* *}$ & $0.24^{* *}$ & $0.28^{* *}$ & $0.30^{* *}$ \\
2. RSE & $3.15(0.46)$ & & 1 & $0.20^{* *}$ & $0.16^{* *}$ & $0.33^{* *}$ & $0.27^{* *}$ & $0.26^{* *}$ & $0.44^{* *}$ \\
3. PSS & $3.75(0.65)$ & & & 1 & $0.23^{* *}$ & $0.25^{* *}$ & $0.19^{* *}$ & 0.07 & 0.13 \\
4. Agreeableness & $4.92(1.14)$ & & & & 1 & 0.08 & $0.16^{*}$ & $0.15^{*}$ & $0.30^{* *}$ \\
5. Extraversion & $4.26(1.49)$ & & & & 1 & $0.20^{* *}$ & 0.01 & 0.11 \\
6. Openness to experiences & $5.16(1.17)$ & & & & & 1 & $0.19^{* *}$ & 0.08 \\
7. Conscientiousness & $4.90(1.22)$ & & & & & & & $0.26^{* *}$ \\
8. Emotional stability & $3.98(1.46)$ & & & & & & & 1 \\
\hline
\end{tabular}

Legend: M: mean; SD: standard deviation; Single-Item Self-Esteem Scale (SISES); Rosenberg Self-Esteem Scale (RSE); Prosocialness Scale (PSS); $*<<0.05$ (two-tailed test); $* * p<0.001$ (two-tailed test).

measured by the SISES based on participants' religion $[\mathrm{F}(3.191)=0.30, p=0.82]$ or sexual orientation $[\mathrm{F}(2.195)=0.14, p=0.87]$. In addition, there were no significant differences using the RSE based on religion $[\mathrm{F}(3.188)=1.115, p=0.35]$, sexual orientation $[\mathrm{F}(2.188)=2.03, p=0.11]$, or family income $[\mathrm{F}$ $(6.188)=0.25, p=0.96]$.

However, significant differences were found in the SISES score based on family income [F (6.195) $=4.01, p<0.01]$, presenting an effect size with a $\eta^{2}$ (partial eta squared) of 0.11 , which demonstrates that approximately $11 \%$ of the variation in the SISES score was due to income differences among participants. The income variable was divided into groups representing intervals of amounts in Brazilian reais (BRL): income 1 (0-788.00), income 2 (789.00-1,576.00), income 3 $(1,577.00-2,364.00)$, income 4 (2,365.00-4,728.00), income 5 (4,729.00-7,092.00), and income 6 (over 7,093.00). A post hoc test (Tukey's honestly significant difference $[\mathrm{HSD}])$ shows that the differences are nonsignificant $(p=0.04)$ between income $1(\mathrm{M}=3.96,62$; $\mathrm{SD}=1.39)$, income $4(\mathrm{M}=4.67 ; \mathrm{SD}=13.98)$, and income $5(\mathrm{M}=4.85$; $\mathrm{SD}=1.38)$.

In addition, regarding the analyses of the sources of variations in self-esteem levels, this time comparing two conditions, Student's $t$ tests for independent samples were conducted using two of the participants' other socio-demographic variables: gender and educational institution. The results show a significant difference using the SISES $(\mathrm{t}(200)=3.83 ; p<0.001 ; \mathrm{d}$ $=0.56)$ and the RSE $(\mathrm{t}(186)=3.80 ; p=0.02 ; \mathrm{d}=0.33)$, between participants based on gender. In addition, for both instruments, males presented higher self-esteem levels. In the SISES specifically, there was a difference in the means of 0.75 , with a confidence interval $(\mathrm{CI}=$ $95 \%)$ of 0.36 to 1.13 , suggesting that males $(M=4.84$, $\mathrm{SD}=1.35)$ presented higher scores than females $(\mathrm{M}=$ 4.09; $\mathrm{SD}=1.34)$.

In addition, there was also a significant difference between the means using the SISES $(\mathrm{t}(194)=4.59 ; p<$ $0.001 ; \mathrm{d}=0.68)$ and the RSE (t $(194)=2.14 ; p=0.03$; $\mathrm{d}=0.30$ ) between participants based on type of institution, with students from public institutions presenting higher self-esteem levels. In the SISES specifically, a difference of 0.89 was found, with a $95 \%$ CI of 0.50 to 1.27 , suggesting that participants from public institutions $(\mathrm{M}=4.71$; $\mathrm{SD}=1.42)$ had higher self-esteem compared with those from private institutions $(\mathrm{M}=$ 3.82; $\mathrm{SD}=1.18$ ).

Subsequently, the degree to which self-esteem correlates with level of religiosity and with participants' self-perception regarding being a good student was analyzed. Pearson's $r$ correlation analysis and a twotailed test were conducted with these variables, as the direction of the correlation was unknown. The results show positive and significant correlations between level of self-esteem and degree of religiosity measured through the SISES $(r=0.15 ; p=0.03)$ and the RSE $(r=0.20 ; p<0.001)$ and between level of self-esteem and the perception of being a good student using the SISES $(r=0.16 ; p=0.02)$ and the RSE $(r=0.31 ; p<$ $0.001)$. This indicates that individuals with higher levels of religiosity and self-perception as a student have higher self-esteem. 


\section{Discussion}

Based on the results of this study, the SISES presented satisfactory psychometric qualities in terms of convergent validity, corresponding to the minimum value recommended for research (Pasquali, 2010). Thus, this study provides relevant support for the convergence between the SISES and the RSE, one of the most widely used instruments to measure self-esteem (Bandeira \& Hutz, 2010; Barros \& Moreira, 2015; Fernandes, Alves, Santos, Mota, \& Fernandes, 2013; Laible \& Roesch, 2004; Orth, et al., 2008; Pimentel, 2012). In addition, the results corroborate the three studies conducted by Robins et al. (2001), which showed high convergent validity between the SISES and the RSE.

Therefore, it is expected that researchers who opt to use the SISES as an alternative to the RSE should find similar correlations. This was confirmed by comparing the results of the correlation analyses, ANOVAs, and $t$ tests, which in their majority had the same direction, with the exception only of the correlations between the agreeableness trait and prosocial behaviors, which were not significant using the SISES. However, this divergence may result from a lack of consensus with regard to the definition of prosocial behaviors, as indicated by Batson and Powell (2003), who state that although altruism is included in the broad definition of prosocial behaviors, this construct differs, for instance, from the behavior of helping, as it presents an implicit interest.

Given the practicality of the SISES as it consists of a single item, this instrument is a helpful alternative in terms of measuring self-esteem in various contexts, in particular when little time is available and conditions are not favorable to administering a lengthier instrument (e.g., waiting lines, movie theaters, plazas, exams such as the university entrance examination).

In addition, it was found that the SISES as well as the RSE presented significant correlations with the TIPI, demonstrating that self-esteem correlated positively with the personality factors of extraversion, openness to experiences, conscientiousness, and emotional stability. Robins et al. (2001) corroborate these results regarding self-esteem's relationship with extraversion, emotional stability, and conscientiousness. Other studies (Hutz, et al., 2014; Nunes, Hutz, \& Nunes, 2008) also show a positive correlation between self-esteem and emotional stability. These data suggest that individuals who are communicative, emotionally positive, fun-loving, open to new experiences, and goal-oriented have increased self-esteem.
Regarding the differences in self-esteem among groups based on socio-demographic variables, significant results were found for gender, family income, educational institution, level of religiosity, and the self-perception of being a good student. Regarding gender, male participants showed higher levels of self-esteem than females, which agrees with the results of previous studies, such as Bandeira and Hutz (2010). These researchers evaluated the impact of bullying on the self-esteem of adolescents and found that boys who engaged in bullying presented higher self-esteem than girls.

Individuals with higher incomes scored higher on the self-esteem scale than individuals with low income. No studies evaluating differences among groups based on these variables or correlational studies exist in the literature. Therefore, further studies evaluating this relationship are needed.

There were significant differences between students from public educational institutions and students from private institutions. The students from public universities scored higher on the self-esteem scale. No study on this relationship was found. However, Terra (2011) compared the self-esteem of professors from public and private institutions and found that professors from public universities had higher levels of self-esteem.

Regarding religiosity, the positive correlation found corroborates the findings of Krause (2003), who analyzed religious meaning and subjective wellbeing in adults. The study showed that individuals who derive a sense of meaning in life from religion tended to exhibit a higher level of life satisfaction, self-esteem, and optimism. In addition, Fernandes et al. (2013) conducted a study with mastectomized women and found that the women exhibited a strong sense of religiosity, which provided a change in life perspective and influenced the expression of increased self-esteem.

Finally, a positive and significant correlation between the perception of being a good student and high levels of self-esteem was found. This suggests that the effort to perform well in academic settings is directly related to the self-esteem level of the student who is often concerned with his/her performance. However, other studies in this field did not find significant differences based on these variables (Peixoto; 2004; Senos, 1996; 1997).

\section{Final considerations}

The objective of the present study was to adapt and gather evidence of validity of the SISES and to 
verify the influence of socio-demographic variables. The results appear to be reliable. However, further studies with larger and more heterogeneous samples and in other contexts are recommended to provide a deeper and more detailed knowledge of the SISES and its correlates. In addition, the use of probabilistic sampling may contribute to the generalization of the results.

The use of a convenience sampling in this study is a limitation. However, the number of participants was sufficient to conduct the statistical analyses (Clark \& Watson, 1995). Therefore, researchers and interested individuals have the opportunity to rely on a shorter instrument to measure self-esteem.

In summary, the results show that the SISES has good psychometric quality in terms of convergent validity with the RSE and is even more parsimonious. Thus, it is concluded that the SISES is a reliable measure to be used in scientific studies on self-esteem and is a brief and easy-to-administer instrument to evaluate this construct. Moreover, this study presents relevant results and expands the knowledge base regarding self-esteem, in addition to confirming the correlates between this construct and personality traits and sociodemographic variables.

\section{References}

Allport, G. W. (1973). Personalidade: padrões e desenvolvimento. São Paulo: EPU

Assis, S. G. \& Avanci, J. Q. (2004). Labirinto de espelhos: formação da auto-estima na infância e na adolescência. Rio de Janeiro: Fiocruz.

Avelar, C. F. P., \& Veiga, R. T. (2013). Como entender a vaidade feminina utilizando a autoestima e a personalidade. RAE-Revista de Administração de Empresas, 53(4), 338-349. doi. org/10.1590/S0034-75902013000400002

Bagozzi, R. P., \& Heatherton, T. F. (1994). A general approach to representing multifaceted personality constructs: application to state self-esteem. Structural Equation Modeling: A Multidisciplinary Journal, 1(1), 35-67. doi.org/10.1080/10705519409539961

Bandeira, C. M., \& Hutz, C. S. (2010). As implicações do bullying na auto-estima de adolescentes, Psicologia Escolar e Educacional, 14(1), 131-138.

Barreiros, J. M. A. (2012). Automonitoragem: Processo Baseado no comportamento prossocial. Dissertação de
Mestrado. Instituto Universitário - ISPA. Lisboa, Portugal.

Barros, R. M. \& Moreira, A. S. (2015). Desemprego, autoestima e satisfação com a vida: estudo exploratório realizado em Portugal com beneficiários do Rendimento Social de Inserção. Revista Psicologia Organizacional do Trabalho, 15(2). 146-156. doi. org/10.17652/rpot/2015.2.476

Bastianello, M. R., Pacico, J. C. \& Hutz, C. S. (2014). Optimism, self-esteem and personality: adaptation and validation of the Brazilian Version of The Revised Life Orientation Test (LOT-R). Psico-USF, 19(3), 523-531.doi.org/10.1590/1413-827120140190030

Batson, C. D., \& Powell, A. A. (2003). Altruism and prosocial behavior. Em T. Millon \& M. J. Lerner (Eds.), Handbook of psychology: Personality and social psychology (Vol. 5, pp. 463-484). London: Wiley.

Battle, J. (1992). Culture-free self-esteem inventories: Examiners manual (2nd ed.) Austin, TX: Pro-Ed.

Blascovich, J. \& Tomaka, J. (1991). Measures of self-esteem. Em J. P. Robinson \& P. R. Shaver (Eds.), Measures of personality and social psychological attitudes (pp. 115-160). SanDiego, CA: Academic Press.

Brown, J.D., \& Smart, S. A. (1991). The self and social conduct: Linking self-representations to prosocial behavior. Journal of Personality and Social Psychology, 60(3), 368-375. doi. org/10.1037/0022-3514.60.3.368

Caprara GV, Steca P, Zelli A, Capanna C. (2005). A new scale for measuring adult's prosociality. European Journal of Psychological Assessment, 21, 77-89. doi. org/10.1027/1015-5759.21.2.77

Clark, L. A., \& Watson, D. (1995). Constructing validity: Basic issues in objective scale development. Psychological Assessment, 7(3), 309-319. doi. org/10.1037/1040-3590.7.3.309

Coopersmith, S. (1989). Coopersmith - self-esteem Inventory. Palo Alto, CA: Consulting Psychologists Press.

Costa, P. T., Jr., \& McCrae, R. R. (1992). NEO-PI-R professional manual: Revised NEO Personality Inventory (NEO-PI-R) and NEO-Five Factor Inventory (NEO-FFI). Odessa, FL: Psychological Assessment Resources.

Daly, J. A., \& Wilson, D. A. (1983). Writing apprehension, self-esteem, and personality. Research in the Teaching of English, 17(4), 327-341. 
Eisenberg, N. \& Mussen, P. (1989). The roots of prosocial behavior in children. Cambridge: Cambridge University Press.

Fernandes, M. M. J., Alves, P. C., Santos, M. C. L., Mota, E. M., \& Fernandes, A. F. C. (2013). Autoestima de mulheres mastectomizadas aplicação da Escala de Rosenberg. Revista Rene, 14(1), 101-108. Accessed in http://www.revistarene.ufc.br/revista/index.php/revista/article/ view/38

Filho, N. H., Machado, W. L., Teixeira, M. A. P., \& Bandeira, D. R. (2012). Evidências de Validade de Marcadores Reduzidos para a Avaliação da Personalidade no Modelo dos Cinco Grandes Fatores. Psicologia Teoria e Pesquisa, 28(4), 417-423. Accessed in http://www.scielo.br/pdf/ptp/v28n4/07.pdf

Forgas, J. P. (2002). Feeling and doing: Affective influences on interpersonal behavior. Psychological Inquiry, 13(1), 1-28. doi.org/10.1207/ S15327965PLI1301_01

Gebauer, J. E., Riketta, M., Broemer, P., \& Maio, G. R. (2008). "How much do you like your name?" An implicit measure of global self-esteem. Journal of Experimental Social Psychology, 44(5), 1346-1354. doi. org/10.1207/S15327965PLI1301_01

Gosling, S. D., Rentfrow, P. J., \& Swann, W. B., Jr. (2003). A very brief measure of the big-five personality domains. Journal of Research in Personality, 37(6), 504528. doi.org/10.1016/S0092-6566(03)00046-1.

Gosling, S. D., Augustine A.A., Vazire S., Holtzman N. \& Gaddis S. (2011). Manifestations of Personality in Online Social Networks: Self-Reported Facebook-Related Behaviors and Observable Profile Information. CyberPsychology, Behavior and Social Networking. 14(9), 483-488. doi.org/10.1089/ cyber.2010.0087

Hall, C. S., Lindzey, G., \& Campbell, J. B. (2000). Teorias da personalidade (4a ed.). Porto Alegre: Artmed.

Heatherton, T. F. \& Polivy, J. (1991). Development and validation of a scale for measuring state self-esteem. Journal of Personality and Social Psychology, 60(6), 895-910. doi.org/10.1037/0022-3514.60.6.895

Heatherton, T. F. \& Wyland, C. (2003). Assessing self-esteem. Em S. Lopez \& R. Snyder, (Eds). Assessing positive psychology (pp. 219-233). Washington, DC: APA. doi.org/10.1037/10612-014
Humphreys, T. (2001). Auto-estima: a chave da educação para seu filho. São Paulo: Ground.

Hutz, C. S. (2000). Adaptação da escala de autoestima de Rosenberg. Manuscrito não publicado. Universidade Federal do Rio Grande do Sul. Porto Alegre, RS.

Hutz, C. S., Midgett, A., Pacico, J. C., Bastianello, M. R., \& Zanon, C. (2014). The relationship of hope, optimism, self-esteem, subjective well-being, and personality in Brazilians and Americans. Psychology, 5(6), 514-522. doi: 10.4236/ psych.2014.56061

Hutz, C. S., \& Zanon, C. (2011). Revisão da adaptação, validação e normatização da Escala de Autoestima de Rosenberg. Avaliação Psicológica, 10(1), 41-49.

Isen, A. M., \& Levin, P. F. (1972). The effect of feeling good on helping: cookies and kindness. Journal of Personality and Social Psychology, 21(3), 384-388. doi. org $/ 10.1037 /$ h0032317

Koller, S. H. (1997). Educação para pró-sociabilidade: uma lição de cidadania? Paidéia, 12, 39-50. doi. org/10.1590/S0103-863X1997000100004.

Krause, N. (2003). Religious meaning and subjective wellbeing in later life. Journal of Gerontology: Social Sciences, 58(3), 160-170. http://dx.doi.org/10.1093/ geronb/58.3.S160

Laible, D. J., Carlo, G., \& Roesch, S. C. (2004). Pathways to self-esteem in late adolescence: The role of parent and peer attachment, empathy, and social behaviours. Journal of Adolescence, 27(6), 703-716. doi.org/10.1016/j.adolescence.2004.05.005

Nunes, C. H. S. S., Hutz, C. S., \& Nunes, M. F. O. (2008). Bateria Fatorial de Personalidade (BFP). Manual Técnico, São Paulo: Casa do Psicólogo.

Orth, U., Robins, R. W. \& Roberts, B. W. (2008). Low self-esteem prospectively predicts depression in adolescence and young adulthood. Personality Processes and Individual Differences, 95(3), 695-708. doi. org/10.1037/0022-3514.95.3.695

Pasquali, L. et al. (2010). Instrumentação Psicológica. Fundamentos e Práticas. Porto Alegre: Artmed.

Peixoto, F. (2012). Qualidade das relações familiares, auto-estima, autoconceito e rendimento académico. Análise Psicológica, 22(1), 235-244. doi. org/10.14417/ap.144

Penner, L. A., Dovidio, J. F., Piliavin, J. A., \& Schroeder, D. A. (2005). Prosocial behavior: 
Multilevel perspectives. Annual Review of Psyschology, 56, 365-392. doi.org/10.1146/annurev. psych.56.091103.070141

Pimentel, C. E. (2012). Efeitos de letras de músicas em comportamentos pró-sociais: teste do modelo geral da aprendizagem. PhD Dissertation. Universidade de Brasília.

Pimentel, C.E., Ferreira, D.C.S., Vargas, M.M., Maynart, V.A.P., \& Cardozo, D.C. (2014). Preferência por estilos de filmes e suas diferenças nos cinco fatores de personalidade. Pesquisas e Práticas Psicossociais, 9(2), 233-244.

Robins, R. W., Hendin, H. M., \& Trzesniewski, K. H. (2001). Measuring global self-esteem: Construct validation of a single-item measure and the Rosenberg self-esteem scale. Personality and Social Psychology Bulletin, 27(2), 151-161. doi. org $/ 10.1177 / 0146167201272002$

Robins, R. W., Tracy, J. L., Trzesniewski, K. H., Potter, J., \& Gosling, S. D. (2001). Personality correlates of self-esteem. Journal of Research in Personality, 35(4), 463-482. doi.org/10.1006/jrpe.2001.2324

Roche, O. R. (2010). Prosocialidad nuevos desafios: métodos y pautas para la optimización creativa del entorno. Buenos Aires, Argentina: Ciudad Nueva.

Rosenberg, M. (1989). Society and the adolescent self-image. (Revised Edition). Middletown, CT: Wesleyan University Press.

Schultheisz, T. S. V. \& Aprile, M. R. (2013). Autoestima, conceitos correlatos e avaliação. Revista Equilíbrio Corporal e Saúde, 5(1), 36-48. Accessed in http:// www.pgsskroton.com.br/seer/index.php/reces/ article/view/22

Senos, J. (1996). Atribuição causal, auto-estima e resultados escolares. Análise Psicológica, 1(14), 111-121. Accessed in http://repositorio.ispa.pt/ bitstream/10400.12/3538/1/AP_1996_1_111.pdf

Schmitt, D. P., Allik, J., McCrae, R. R., Benet-Martinez, V., Alcalay, L., Ault, L. et al. (2007).
The geographic distribution of big five personality traits: Patterns and profiles of human self-description across 56 nations. Journal of Cross-Cultural Psychology, 38(2), 173-212. doi. org/10.1177/0022022106297299

Simkin, H, \& Azzollini, S. (2015). Personalidad, autoestima, espiritualidad y religiosidad desde el modelo y la teoría de los cinco factores. Revista Latinoamericana de Ciência Psicológica, 7(2), 339-361. doi. org/10.5872/psiencia/7.2.22

Sousa, V., \& Rojjanasrirat, W. (2010). Translation, adaptation and validation of instruments or scales for use in cross-cultural health care research: A clear and user friendly guideline. Journal of Evaluation in Clinical Practice, 17(2), 268-274. doi. org/10.1111/j.1365-2753.2010.01434.x

Stobaus, L. C. (2013). Desenvolvimento prossocial em crianças de três anos de idade: relações do contexto sócio afetivo de criação e da depressão materna. $\mathrm{PhD}$ Dissertation. Universidade de São Paulo, São Paulo, Brasil.

Terra, F. D. S. (2010). Avaliação da ansiedade, depressão e autoestima em docentes de Enfermagem de universidades pública e privada. PhD Dissertation. Universidade de São Paulo, São Paulo, Brasil.

Thompson, E. R. (2008). Development and validation of an International English Big-Five Mini-Markers. Personality and Individual Differences, 45(6), 542-548. doi.org/10.1016/j.paid.2008.06.013

Urbina, S. (2007). Fundamentos da Testagem Psicológica. Porto Alegre: Artmed.

Weisskirch, R. S. (2016). Grit, Self-Esteem, Learning Strategies and Attitudes and Estimated and Achieved Course Grades among College Students. Current Psychology, 1, 1-7. doi:10.1007/ s12144-016-9485-4

Recebido em: 18-02-2016

Reformulado em: 12-09-2016; 04-10-2016

Aprovado em: 14-10-2016 
Sobre os autores:

Carlos Eduardo Pimentel is adjunct professor at Department of Psychology in Federal University of Paraíba. He is also professor of the Pos-Graduation Program of Social Psychology (Master and Doctorate). He has PhD in Organizacional, Work and Social Psychology from Brasilia University.

E-mail: carlosepimentel@bol.com.br

Flávia Marcelly de Sousa Mendes da Silva, Graduation in Psychology, Master in Social Psychology in Federal University of Paraíba and PhD student in Social Psychology at the Federal University of Paraíba

E-mail: flaviamarcelly.psi@hotmail.com

Jérssia Laís Fonseca dos Santos, Graduation in Psychopedagogy and Master in Social Psychology at Federal University of Paraíba.

E-mail: jerssyafonseca@hotmail.com

Karen Guedes Oliveira, Professor of Department of Psychology in UNINASSAU University - João Pessoa-PB. She has PhD in Social Psychology from Federal University of Paraíba.

E-mail: karen_costaguedes@hotmail.com

Nájila Bianca Campos Freitas, Graduation in Psychopedagogy and Master in Social Psychology at Federal University of Paraíba.

E-mail: najila.bianca@hotmail.com

Ricardo Neves Couto is Graduated in Psychology from Federal University of Piauí. Master and PhD student in Social Psychology at Federal University of Paraíba - João Pessoa, PB, Brazil.

Email: r.nevescouto@gmail.com

Tátila Rayane de Sampaio Brito, PhD student in Social Psychology from Federal University of Paraíba, with research interests focused on Social Psychology, Psychological Assessment and Positive Psychology.

E-mail: tatila.rayane@hotmail.com

Contato com os autores:

Rua Eduardo Medeiros, 125

Castelo Branco I, João Pessoa-PB, Brasil

CEP: 58050-080 
